УДК 316.42+681.3.06

DOI https://doi.org/10.32837/apfs.v0i29.964

М. Г. Санакуєв

ORCID ID: https://orcid.org/0000-0001-7725-6117

кандидат філософських наук, старший науковий співробітник

Національної бібліотеки України імені В. І. Вернадського

\title{
МІСЦЕ ПОШУКОВОГО АЛГОРИТМУ В ГЛОБАЛЬНОМУ ІНФОРМАЦІЙНО-КОМУНІКАТИВНОМУ ПРОСТОРІ ТА ЙОГО ЗНАЧЕННЯ В КОНТЕНТ-АНАЛІЗІ
}

Стрімкий перехід людства на дистанційну взаємодію спричинив швидкі зміни в інформаційному просторі, який у глобальному прояві почав підлаштовуватися під користувачів. Як результат всеосяжної економічної інтеграції та рушій багатогранних соціальних, культурних і політичних процесів, новий інформаційний простір дав нові можливості для людської практики в налагодженні системи комунікації та отриманні на цій основі певної вигоди.

Чергова хвиля глобалізації завдяки новим технологіям зробила комунікацію та світ тіснішим і доступнішим для всіх. «Інформаційна революція дала змогу мільйонам людей глобально діяти, глобально спілкуватися, глобально подорожувати й глобально торгувати» [1, с. 13].

Предметом дослідження є пошуковий алгоритм як новітня технологія контент-аналізу. Метою дослідження виступає аналіз особливостей інформативно-комунікативного простору й виокремлення глобальних тенденцій, що впливають на нього. Результати дослідження виявляють причинно-наслідкові зв'язки функціонування та місця пошукового алгоритму в контент-аналізі. Досягнення поставленої мети передбачає розв'язання низки дослідницьких завдань:

- узагальнити зміст підходів щодо проблем інформаційно-комунікативного простору, які пов'язані з глобалізацією;

- визначити особливості функціонування пошукового алгоритму в інформаційно-комунікативному просторі;

- обгрунтувати вплив нових технологій на контент-аналіз.

Ураховуючи предмет дослідження та відповідні особливості цього складного явища, були використані історико-порівняльний, структурно-функціональний, прогностичний методи. Історико-порівняльний метод був використаний у форматі аналізу генези поняття інформаційно-комунікативної взаємодії для відстеження тенденцій змін пошукових технологій в інформаційному просторі. Структурно-функціональний метод застосовувався в аналізі нових технологічних надбань, які використовуються в контент-аналізі. Прогностичний метод дозволив сформулювати рекомендації для освоєння та раціонального застосування таких технологій, допоміг розібратися у виявлених тенденціях інформаційних комунікацій сучасних методів і методик вивчення документів.

Вивченням теми впровадження електронних технологій в інформаційно-аналітичну діяльність займались О. Ворошилов, В. Горовий, Р. ЖЖангожа. Дослідженням проблематики пошукового алгоритму серед вітчизняних учених присвячені праці С. Знахур, О. Сухий, О. Мізяк, В. Міленін, В. Тарадайнік; серед закордонних - С. Брін, Н. Ленджвіль, Д. Лєвандовські, Карл Д. Меєр, К. Шерман. Наукові надбання у вивченні контент-аналізу та інформаційної аналітики, що поєднані з технологічною складовою частиною, мають Л. Чирун, Н. Костенко, Л. Чуприна, В. Висоцька, В. Іванов.

Проте існує недостатня наукова розробка низки теоретичних і методологічних аспектів проблем інформації та комунікації у зв'язку з практичними методами соціологічного аналізу й наявність практичних проблем вибору засобів для контент-аналізу, що постійно проявляються на фоні прогресу сучасних комп'ютерних технологій і викликів. Тому, враховуючи всі ці особливості, вони вимагають подальшого наукового вивчення.

I. Пошуковий алгоритм та інформаційно-комунікативний простір сьогодення

Наразі глобальні процеси поступово ламають сталий устрій соціальної взаємодії та переналаштовують систему соціальних комунікацій. Це зумовлено настанням чергової соціальної еволюції та змін, до яких підштовхнула епідемічна криза.

Процеси масштабних змін світу в науковому дискурсі є закономірною тенденцією та віддзеркалюють чинну «світосистему» взаємовідносин між людьми, яку детально описав I. Валлерстайн. Вона побудована за принципом економічної піраміди, в якій є центр і периферія зі своєю взаємодією, що грунтується на основі залежності «хазяїн-робітник». Стійкість взаємодії залежить від мистецтва контролю периферії та задоволенням потреб центру [2].

Представники американської науки під керівництвом Д. Белла займалися проблемами комунікативної взаємодії, що зазнають змін із розвитком 
технологій і мережі Internet. Уже тоді ними було спрогнозовано, що вплив на інтенсивність потоків інформації та зміни контенту будуть вирішальними чинниками трансформації свідомості. Їхня фундаментальна праця «Прогнози до 2000 року», основні висновки якої були надруковані в тижневику «Дедалус», викликали неабияку зацікавленість у широких колах науково-експертного середовища й політиків [3].

Інформаційно-комунікативна взаємодія та інформаційно-комунікативний простір вивчається під різним кутом науки, існує низка різних теорій і концепцій інформаційного суспільства. Досить вдалий аналіз досліджень та узагальнень запропоновано А. Чугуновим, який підсумував досягнення вчених суспільно-гуманітарних наук, що розробляють вищезазначену тему, й дійшов таких висновків: 1) подолання світової бідності приведе світ у стан трансформаційних змін і буде сприяти оновленню традиційних соціальних принципів, структур, моральних норм, уявлень; 2) зростання кількості комунікаційних каналів вплине на стійкість зв'язків у ланцюгу «культура й соціальна структура», що сприятиме вивільненню суспільства й волевиявленню окремо взятої людини; 3) культура стає більш гедоністичною, експресивною та орієнтованою на успіх, який може принести інформаційний і технологічний світ; 4) завдяки поширенню новітніх комунікацій світ стає над ідеологічним простором, а людина вразливішою фізично й психологічно [4].

Вищезазначені наукові надбання в галузі комунікацій можна вважати ключовими, в них грунтовно спрогнозовано основні тенденції цивілізаційного розвитку, визначено центральні проблеми, які має феномен ущільнення комунікативного навантаження в житті людини.

В умовах відкритого інформаційно-комунікативного простору, формуванню якого, починаючи з 90 -х років минулого століття, сприяли Інтернет та інформаційні технології, вчені звернули увагу на особливості спілкування різних культурних типів, мовних контентів і груп за інтересами, які зацікавлені в успішному встановленні комунікативної взаємодії. Цей успіх пов'язують із політикою «м'якого нав'язування» потрібних наративів однією стороною іншій. Така лінія поведінки стала пріоритетною для окремо взятих держав і корпорацій і вийшла за межі державних кордонів [5, c. 249-250].

Наразі спектр наративів досить широкий $\mathrm{i}$ підвладний постійному впливу часу, але є базові сфери, навколо яких відбувається весь науковий дискурс. До них можна віднести економічні, соціальні, політичні, культурні сфери. Прозорість цілей і змісту пошукових алгоритмів у деперсоналізованій мережевій комунікації, як правило, залишається для пересічного користувача в тіні.
У поняттєвому визначенні цю особливість процесу взаємодії в глобальному інформаційно-комунікативному просторі відносять до «стратегічного інструментарію», а він своєю чергою в поєднанні 3 «м'якою силою» та масштабним охопленням Інтернет аудиторії формує явище стратегічних комунікацій.

У період із 1993 по 2000 роки А. Гор був віцепрезидентом США, саме він вперше вжив термін «стратегічні комунікації» та увійшов в історію як «батько Інтернету», ця людина продовжує займати впливові посади в різних медіа й міжнародних корпораціях: Apple Inc., Google, Current [6; 7, c. 144].

Глобалізація як цільова установка вплинула на масову свідомість, і в процесі суспільної взаємодії об'єктом наукової зацікавленості є процес поширення інформації, технології створення контенту й контекстів для успішного проведення комунікації.

Стрімке зростання кількості інформації в мережі Internet привело до потреби в постійному вдосконаленні методів пошуку інформації. 3 появою перших пошукових систем загальна кількість проіндексованих сторінок складала лише десятки тисяч, натепер їхня приблизна кількість складає більйони. А отже, якщо на початку створення пошукових систем могли бути ефективними навіть найпростіші засоби пошуку інформації, нині їх не досить. Ураховуючи це, провідні пошукові системи, такі як Google, постійно впроваджують нові методи для підвищення релевантності результатів пошуку, що відповідають потребам запиту.

Збільшення зацікавленості у Всесвітній павутині як джерелі інформації в умовах різних карантинних обмежень підштовхує до подальшого іï розвитку й удосконалень. Зокрема, це сприяє переведенню значної кількості матеріалів і публікацій в електронну форму. Пошукові системи індексують документи у форматах, відмінних від html, зокрема у форматах, характерних для зберігання наукової інформації, таких як pdf, PostScript, i використовують хмарні сервіси для їх зберігання, що своєю чергою збільшило кількість документів, доступних для пошуку. Варто також відзначити, що ще однією перевагою Internet є легкість розміщення та використання цих матеріалів.

Проте під час пошуку наукових або вузькопрофільних матеріалів через пошукові системи в отриманих користувачем результатах документи наукової тематики можуть взагалі не з'явитись на перших сторінках. Через це дуже часто складається така ситуація: ймовірність знайти якусь статтю незначна, навіть якщо вона проіндексована такою пошуковою системою.

Основною причиною цього $є$ те, що пошукові системи під час визначення релевантності орієнтуються на ключові слова пошукового запиту, що 
задані користувачем. Відповідно, за цими словами не завжди можна визначити тематику документів. Через специфічність цільової аудиторії, зокрема, наукові документи можуть мати значно меншу кількість посилань, що також впливає на визначення релевантності запиту.

Запровадження тематичного розмежування результатів пошуку на рівні пошукової системи за умови сучасних обсягів доступних для пошуку даних потребує значного підвищення складності пошуку. Тому більш виправданим виявилось створення окремих пошукових систем, що спеціалізуються на пошуку наукової інформації.

Натепер найпопулярнішими серед спеціалізованих пошукових систем для пошуку наукової інформації є такі, як CiteSeer, Google Scholar, Scirus. Серед принципів роботи цих пошукових систем варто відзначити такі: пошук на порталах наукового спрямування, наукових видавництв, університетів тощо; пошук документів у форматах, відмінних від html, зокрема pdf i PostScript; урахування цитованості джерела під час ранжування результатів.

Загалом варто відзначити, що спеціалізовані пошукові системи $€$ досить ефективними для пошуку англомовних наукових матеріалів. Проте метод пошуку на порталах наукового спрямування $\epsilon$ не досить ефективним для пошуку україномовних наукових матеріалів, адже такі спеціалізовані ресурси зберігання інформації є менш характерними для української частини Internet. Підтримка пошуку україномовних матеріалів у більшості систем реалізована не повністю, що призводить до зменшення релевантності результатів пошуку українською мовою. Усе це вкотре свідчить про актуальність подальших досліджень у галузі ефективності пошуку наукових матеріалів.

Поява Всесвітньої павутини в 1989 році значно змінила підходи до пошуку інформації, оскільки Internet як колекція документів має певні унікальні риси: 1. Велика кількість документів. За даними Google, на 2008 рік налічувалось близько 1 трильйона унікальних посилань. 2. Динамічність. Документи постійно додаються та оновлюються. Так, на початок 2000 року їх кількість сягала декількох більйонів, а на січень 2004 вже була більшою за 10 більйонів. 3. Самоорганізованість. На відміну від традиційних зібрань документів, де їх додаванням і зберіганням займаються спеціалісти, у Всесвітній павутині користувачі здатні самостійно додавати, змінювати й вилучати інформацію. 4. Інформація взаємопов'язана за допомогою посилань [9].

Це зумовило розвиток пошукових систем, орієнтованих на автоматичний пошук великої кількості інформації. Ситуація змінилась, коли в 1998 році в Стенфордському університеті в рамках дослідницького проєкту була створена Google.
Google - це гра зі словом googol (гугол). Гугол це число десять у сотому ступені, тобто одиниця зі ста нулями. Використання цього терміна відбиває мету компанії Google зробити доступним для пошуку весь, практично нескінченний масив інформації, що розміщена в Інтернет [8].

У січні 1996 року Лоуренс Пейдж і Сергій Брін почали спільну розробку пошукового сервера Backrub, що одержав свою назву за нетривіальне вміння аналізувати так звані «зворотні посилання», що вказують на ту або іншу сторінку 3 інших ресурсів Internet. Їхній унікальний підхід до аналізу посилань отримав непогану репутацію та популярність. Backrub зростала. Як результат цих розробок, у 1998 з' явилась пошукова система Google [9].

Натепер більшість пошукових систем поєднують оцінку посилань із традиційною оцінкою інформації. Основними моделями пошуку інформації є булева, векторного простору, ймовірнісна.

Булева модель передбачає повне зівставлення документу й запиту користувача. Назва використовується завдяки наявності булевої алгебри, оскільки слова в запиті логічно пов'язуються булевими операторами I, АБО й запереченням.

Модель векторного простору - для неї характерна трансформація текстових даних у числові вектори й матриці й виявлення ключових зв' язків у тексті за допомогою аналізу матриць.

У ймовірнісній моделі документи ранжуються відповідно до величин релевантності (прямо пропорційно ймовірності їх відповідності запиту й обернено пропорційно ймовірності того, що вони не відповідають запиту).

Щодо побудови сучасних пошукових систем, то вона досить різноманітна. Нижче наведено перелік деяких із них:

- crawler (павук) - здійснює сканування Інтернет-ресурсів у пошуках інформації, зберігає та категоризує їі;

- репозиторій сторінок - зберігає сторінки, повернуті павуками, але ще не проіндексовані, або популярні сторінки;

- модуль індексування - створює стиснутий опис сторінки, будує бази даних за ключовими словами;

- індекси - зберігає бази даних за ключовими словами у вигляді, зручному для пошуку за ними;

- модуль запитів - перетворює запит користувача природною мовою на мову пошукової системи й надає запити до індексів;

- модуль ранжування - отримує набір релевантних даних і ранжує їх відповідно до певного критерію (найчастіше за оцінкою змісту й популярності) [10].

Класифікаційні інформаційно-пошукові системи - різновид систем, в яких використовується ієрархічна (деревоподібна) організація інформації, 
котра називається класифікатором. Розділи класифікатора називаються рубриками. Бібліотечний аналог класифікаційної інформаційно-пошукової системи - систематичний каталог. Класифікатор розробляється та вдосконалюється колективом авторів. Потім систематизатори читають документи й відносять їх до певного розділу класифікатора.

Предметна інформаційно-пошукова система полягає в тому, що з кожною назвою пов'язані списки відповідних ресурсів у Інтернет. Такі системи є доволі ефективними при невеликих обсягах інформації.

Словникові інформаційно-пошукові системи полягають у тому, що культурні проблеми, пов' язані з використанням класифікаційних інформаційно-пошукових систем, привели до створення інформаційно-пошукових систем словникового типу з узагальнювальною назвою “search engines". Основна ідея словникової інформаційно-пошукової системи - створити словник зі слів, що зустрічаються в документах Інтернет, в котрому за кожним словом буде зберігатись список документів, 3 яких взято таке слово.

Є два основних алгоритми роботи словникових інформаційно-пошукових систем: із використанням ключових слів і 3 використанням дескрипторів.

У першому випадку для оцінки складу документу використовуються лише ті слова, що в ньому зустрічаються, та за запитом інформаційно-пошукова система співвідносить слова із запиту зі словами з документа й визначає за кількістю, розташуванням, вагою слів із запиту в документі його релевантність. Усі сучасні інформаційно-пошукові системи використовують цей алгоритм у різних його модифікаціях.

Під час роботи з дескрипторами документи, що індексуються, перекладаються на деяку дескрипторну інформаційну мову. Дескрипторна мова складається 3 алфавіту (символів), слів, засобів вираження парадигматичних і синтагматичних зв'язків між словами. Парадигматика передбачає виявлення прихованих у природній мові лексико-семантичних зв' язків між поняттями. У межах парадигматичних зв'язків можна розглядати, наприклад, синонімію, омонімію. Тобто запит користувача переводиться в дескриптори й обробляється інформаційно-пошуковими системами вже в цьому вигляді. Такий підхід потребує більших обчислювальних ресурсів, але й потенційно продуктивніший, оскільки дозволяє відмовитись від критерію релевантності й працювати безпосередньо з пертинентністю документів.

Натепер найчастіше вся пошукова інформація, навіть копії документів, зберігається в пошуковій системі. Це було зумовлено ненадійністю початкових каналів зв'язку й обладнання та надавало можливість користувачу системи фактично незалежно від доступності документу ознайомитись із ним. Проте зараз це призводить до того, що системи змушені збільшувати свої обчислювальні потужності пропорційно до збільшення кількості документів в Інтернет.

У зв'язку із цим постає проблема оновлюваності проіндексованих сторінок. Вона є також важливою для пошуку наукових матеріалів, коли існує потреба в актуальній інформації. Так, Д. Левандовським було проведене дослідження, в якому протягом 2005, 2006 та 2007 років були досліджені терміни оновлюваності сторінок у найбільших пошукових системах (Google, Yahoo та MSN). Згідно із цим дослідженням на тестовій вибірці із 40 сторінок максимально довгий термін оновлюваності досліджуваних матеріалів у 2007 році становив близько двох днів для Google та Yahoo i 5,7 для MSN. Найдовший термін 3 усіх документів у Google становив 175 днів, у MSN - 30 [11].

Інша проблема сучасних пошукових систем - «невидимий веб» (invisible web). Цей термін з'явився ще в 1994 році. Його використав Джілл Іллсворт (Jill Ellsworth) для позначення джерел, що з тих чи інших причин недоступні для звичайних пошукових систем. Синонімами цього терміну є «темний веб» (dark web) або «глибокий веб» (deep web) [12].

Основною причиною, з якої джерела потрапляють до невидимої частини вебу, є їхній інтерактивний характер. Декілька основних причин:

1. Доступні через веб бази даних, що динамічно генерують інформаційні сторінки після виконання запитів користувача, не можуть бути проіндексовані звичайними пошуковими машинами, що рухаються за посиланнями.

2. Інформація, що розміщена не в традиційному для вебу html-форматі.

Одним із кроків у подоланні цієї проблеми був початок індексування в лютому 2001 року системою Google файлів у pdf-форматі. У лютому 2001 року Google додав також до переліку підтримуваних форматів і інші. Це надало змогу, зокрема, збільшити проіндексовану частину наукових матеріалів, оскільки більшість ї викладено саме у форматах “.doc” i “.pdf” [12].

Проте найважливішою проблемою пошуку наукових матеріалів через пошукові системи є те, що під час ранжування не враховується тематика документа, що призводить до великої кількості «шуму» в результатах пошуку. Один із варіантів розв'язання цієї проблеми - це створення спеціалізованих систем пошуку наукових матеріалів.

Отже, основні риси сучасних пошукових систем: великі обсяги проіндексованих сторінок; динамічність; потужність. Проте для них характерна відсутність методів виокремлення наукової інформації, що робить їх не досить ефективними 
в пошуку наукових матеріалів. Проведений аналіз пошукових систем, методів пошуку інформації та їх практичне застосування - досить складний процес.

Сам алгоритм пошуку інформації та інтерес до питання про пошук інформації в мережі Інтернет не слабшає протягом усього часу існування мережі. Пошук може вестися як користувачем-любителем, так і професіоналом. Під час проведення пошуку інформації, що задовольняє інформаційним потребам користувача, необхідно знати, від чого залежить успішний пошук та які проблеми виникають під час роботи з інформацією. Узагальнений алгоритм пошуку інформації в інформаційно-пошуковій системі мережі Інтернет можна представити такою послідовністю дій: формування завдання на пошук інформації; вивчення предметної області завдання на пошук; підготовка пошукового образу й пошукового припису; вибір інформаційно-пошукової системи Інтернет; введення URL-адреси; введення пошукового припису; аналіз пошукового результату або уточнення пошукового припису, якщо результат відсутній; завершення пошуку, якщо результат задовольняє інформаційну потребу [13].

На основі запропонованого найпростішого алгоритму пошуку інформації розроблено модель, що дає можливість перейти до автоматизованого смислового пошуку інформації в розподілених інформаційно-пошукових системах мережі Інтернет.

Узагальнений алгоритм реалізації моделі пошуку в розподілених інформаційно-пошукових системах мережі Інтернет виглядає таким чином:

1. «Зразок документа» (смислова задача), що являє собою шаблон пошуку, вводиться експертом вручну.

2. 3 документа виділяється тема запиту й визначаються пошукові приписи.

3. Розширюється тема запиту шляхом синонімії та асоціативних запитів.

4. Формується пошуковий образ запиту на основі частотного словника 3 розбивкою його на окремі пошукові приписи.

5. Проводиться первинний пошук посилань на релевантні документи в наявних пошукових Інтернет-машинах, загальний результат поміщається в сховищі даних.

6. Здійснюється закачування знайдених документів у сховище даних.

7. Для кожного документа в сховищі даних формується пошуковий образ документа.

8. Проводиться ранжування документів відповідно до заданої теми (п. 2). Чим точніший зміст у тілі документа, тим він має вищий рейтинг.

9. Проводиться реферування знайдених документів і здійснюється передача рефератів для ознайомлення та аналізу експерту відповідно до рейтингу [14].
Запропонований підхід до організації смислового пошуку інформації в розподілених інформаційних системах мережі Інтернет дозволяє якісно поліпшити результати пошукових запитів до пошукових машин мережі Інтернет, автоматизувати процес обробки релевантної інформації з ранжируванням смислової інформації відповідно до заданої теми, що дає можливість експертам відійти від ручного послідовного перегляду знайдених ресурсів.

Засоби масової інформації відбивають дійсність сьогодення та всього, що відбувається довкола. Наразі вони займають важливу роль у житті людини й соціуму, які, користуючись сучасними технологічними досягненнями, споживають ту чи іншу інформацію та не завжди використовують певні фільтри у вигляді додатків і програмного забезпечення. Пересічна людина зазвичай використовує стандартні пошукові системи й не усвідомлює всіх ризиків, що пов'язані з алгоритмами, прописаними машинами.

II. Значення пошукового алгоритму в контент-аналізі

Контент-аналіз або аналіз змісту засобів масової інформації з'явився ще в 40-50-ті роки минулого століття, коли у світі була складна політична обстановка. I саме завдяки аналізу 3MI можна було зробити висновки про внутрішню суспільно-політичну, економічну й культурну ситуацію в середині закритих держав на кшталт окупованої в післявоєнний період Радянським Союзом Німеччини та Європи. Завдяки вивченню змісту газет можна було зрозуміти, що відбувалося в країні, й навіть надати певні прогнози на майбутнє.

Одним 3 авторів методу контент-аналізу $€$ Гарольд Лассвел, що створив «Теорію політичної пропаганди», яка є класичною працею із соціальних комунікацій. Саме Лассвел є автором алгоритму аналізу акту комунікації [15].

До переваг і надбань методу контент-аналізу належить ненав'язливість, тобто відсутність фонового забарвлення, що може впливати на дослідників. Соціолог не займається збором первинної інформації через опитування, а опосередковано збирає дані без прив'язки до території, часу чи простору, в якому відбувається дослідження. Зрештою, зібрані дані з різних джерел легко можна звести в одну таблицю, систематизувати й проаналізувати, надавши прогноз на майбутне.

До контент-аналізу висувається ряд вимог. Самі тексти мають бути репрезентативними, тобто вони мають відповідати запиту замовника дослідження, чітко характеризувати використані для аналізу 3MI. Водночас текстів контенту має бути використано досить велика кількість, що показує професійний рівень соціолога. Також кількість публікацій ЗМІ заздалегідь визначається, вона 
може бути прив'язана до проміжних рамок аналізу: тиждень, місяць, рік. Таким чином, аналізується весь масив публікацій, а самі тексти в цих 3МІ вичитуються від початку й до кінця без визначення, які вони саме: інформаційні, розважальні, рекламні чи повідомлення-оголошення. Вивчається весь масив інформації. I найголовніше: до дослідження має бути застосована наукова строгість, все має бути виконано ретельно й відповідно до плану дослідження.

План контент-аналізу передбачає ряд моментів: наявність сформульованої соціальної проблеми; висунута гіпотеза щодо досліджуваного явища; сформульоване поле змістовних одиниць; використання додаткових методів досліджень для підтвердження результатів.

Загальна характеристика методу контент-аналізу зазвичай однакова, проте є практичні пропозиції та новації для таких досліджень. Метою таких пропозицій нарешті є доступність і простота пошуку необхідної бази для досліджень. Пошук нових механізмів аналізу 3MI насамперед пов'язаний із практикою використання методу [16].

У науково-методичному плані соціологами розглядається розвиток основних жанрів інформаційно-аналітичних продуктів у процесі задоволення запитів замовників, їх подальше вдосконалення за допомогою активного зворотного зв' язку. Це співробітництво дало можливості в режимі реального часу уточнювати актуальну проблематику кінцевого продукту контент-аналізу й оперативно реагувати на потреби в зміні форм подання матеріалів [17; 18; 19].

3 метою вивчення наявності електронних джерел інформації соціолог змушений виконувати роботу з підготовки інформаційної карти регіону, який досліджується. На базі створеної карти має розроблятися каталог-довідник сайтів регіону дослідження. Як результат розширення мережі Інтернет постійно з'являються нові електронні джерела, що ускладнюють роботу, а сам метод контент-аналізу переходить у новий електронний вимір.

Вдалим прикладом підвищення ефективності роботи й встановлення зв'язку із замовником $\epsilon$ застосування методики в режимі «інформація на базі інформації» з урахуванням інтересів замовників та їхніх актуальних потреб у регіонах дослідження [16, с. 32].

У рутині практичних нюансів нагальною постає проблема вибору технічних засобів для контент-аналізу й узгодження пошукового алгоритму. Збір даних для дослідження - один із найважливіших етапів контент-аналізу, а тому для дотримання плану виконання дослідження використовуються агрегатори новин. Така практика застосовується науковцями Служби інформаційно-аналітичного забезпечення органів державної влади (далі CIA3) під час виконання науково-дослідних робіт.
Під керівництвом Л. Чуприни й В. Горового вивчаються різні підходи до освоєння зростальних масивів нової інформації, що дедалі більше використовується в контент-аналізі. Поряд із продукцією вітчизняних видавництв і періодикою зарубіжної друкованої продукції наукові співробітники опановують підходи до розвитку принципово нових джерел інформування - інтернет-видань і продукції аналітичних центрів. Зокрема, виробляються власні механізми аналізу регіональних пресових видань та інших джерел інформації, встановлюються зв'язки з інформаційно-аналітичними структурами в регіонах держави [19; 16, с. 125-128].

Такий підхід дає соціологам не тільки можливості розробки постійно поновлюваних баз даних, які використовуються для контент-аналізу, але й створюють нові нагоди для замовників досліджень. Дуже часто такі бази даних використовуються органами державної влади, щоб вивчити ставлення 3МІ до проблем суспільного життя в регіонах, для відстежування динаміки процесів, що відбуваються в суспільстві.

Підсумовуючи, варто зауважити, що явище пошукового алгоритму до кінця не вивчене, а глобалізаційні процеси змін створюють підгрунтя для наукових розвідок. Наразі маємо два головних вектори розвитку феномену пошукового алгоритму: в площині соціологічно-комунікативних теорій і в площині інформаційно-комунікативних технологій.

У результаті проведених досліджень сучасного стану інформаційно-комунікативної взаємодії, ознайомившись із різними науковими підходами до проблеми пошуку наукової інформації, було узагальнено зміст підходів щодо проблем інформаційно-комунікативного простору, які пов' язані з глобалізацією:

1) подолання світової бідності приведе світ у стан трансформаційних змін і буде сприяти оновленню традиційних соціальних принципів, структур, моральних норм, уявлень;

2) зростання кількості комунікаційних каналів вплине на стійкість зв'язків у ланцюгу «культура й соціальна структура», що сприятиме вивільненню суспільства й волевиявленню окремо взятої людини;

3) культура стає більш гедоністичною, експресивною та орієнтованою на успіх, який може принести інформаційний і технологічний світ;

4) завдяки поширенню новітніх комунікацій світ стає над ідеологічним простором, а людина вразливішою фізично й психологічно

Метод соціологічних досліджень контент-аналіз не втрачає своєї актуальності в глобалізованому світі, він продовжує набирати актуальності в умовах епідемічних обмежень і переходу економіки в онлайн. На фоні цього вплив нових 
технологій на контент-аналіз беззаперечний для того, щоб не поверхнево розбиратися в тенденціях, а глобально стати просунутими користувачами сучасних методів і методик вивчення документів. У підсумку науковець зобов' язаний постійно вдосконалювати свої знання в напрямі комп'ютерних технологій, слідкувати за власною матеріальнотехнічною базою.

Виходячи із завдань, які зазначені на початку роботи, було розглянуто особливості функціонування пошукового алгоритму в інформаційно-комунікативному просторі. Проведено аналіз пошукових систем, методів пошуку інформації та їх застосування в науковому середовищі. На базі практичного досвіду й надбань фахівців у комп'ютерних науках, проаналізованих методів виокремлено рекомендації підвищення ефективності пошуку наукових матеріалів і покроковий механізм дій для користувачів.

Подальше застосування практичного досвіду й підвищення ефективності пошуку має сенс, враховуючи те, що цільовою тематикою пошуку є саме соціологічні дослідження. У результаті виникла пропозиція щодо використання практичного досвіду наукових установ, що діють в Україні. Наукові розробки можуть також застосовуватися для створення прототипів комп'ютерних програм i додатків пошуку україномовних наукових матеріалів, які будуть використовуватись для контентаналізу.

\section{Jimepamypa}

1. Фрідмен Т.Л. Лексус і оливкове дерево. Львів, 2002. $621 \mathrm{c}$.

2. Валлерстайн И. Микросистемный анализ. Вреля мира. Альланах совреленных исследований по теоретической истории, макросоциологии, геополитике, анализу мировых систем и иивилизаций. 1998. Выпуск 1. С. 105-123.

3. Bell D. The third technological revolution and its possible socioeconomic consequences. Dissent. 1989. Vol. 367. № 2. P. 165-172.

4. Чугунов А.В. Теоретические основания концепции «Информационного общества». Санкт-Петербург, $2000.52 \mathrm{c}$.

5. Копійка В.В., Грубов В.М., Даниленко С.I. Homo informaticus епохи постіндустріалізму: витоки, ідеї, ризики (соціокомунікативний вимір) : монографія / за. ред. О.Т. Малієнко. Київ, 2019. 498 с.

6. Al Gore. URL: https://algore.com/about (дата звернення 29.03.2021).

7. Грубов В.М., Санакуєв М.Г. Філософія і методологія соціальних комунікацій : хрестоматія. Київ, 2016. $193 \mathrm{c}$.

8. Попова Т.В., Ліпкан В.А. Стратегічні комунікації : словник / за заг. ред. В.А. Ліпкана. Київ, 2016. $416 \mathrm{c}$.

9. Brin S., Page L. The Anatomy of a Large-Scale Hypertextual Web Search Engine. Computer Networks. 1998. № 30 (1-7). P. 107-117.
10. Langville Amy N., Meyer Carl D. Google's PageRank and Beyond. Princeton, 2006. 224 p.

11. Lewandowski D. A three-year study on the freshness of Web search engine databases. Journal of Information Science. 2008. № 34 (6). P. 817-831

12. Sherman C., Price G. The invisible web: uncovering sources search engines can't see. Library trends. 2003. vol. 52(2). P. 282-298.

13.Знахур С.В. Алгоритми пошуку релевантних документів у інформаційних мережах. Систели обробки інформацї̈. 2012 . № 8 (106). С. 20-23.

14. Сухий О.Л. Алгоритми пошуку в інформаційних системах: методичні рекомендації / за ред. О.Л. Сухий, В.М. Міленін, В.М. Тарадайнік. Київ, 2015. 71 с.

15. Lasswell D. World Politics and Personal Insecurity. New York, 1935. 307 p.

16. Національна бібліотека України імені B.I. Вернадського в науково-інформаційному просторі (2000-2018) : монографія / В.М. Горовий, В.В. Струнгар та ін. ; ред. В.М. Горовий. Київ : НБУВ, 2019. 344 с.

17. Онищенко О.С. Адаптація бібліотек до «життя в цифрі». Бібліотечний вісник. 2020. Вип. 1. С. 3-8.

18. Костенко Н.В., Іванов В.Ф. Досвід контент-аналізу: Моделі та практики : Монографія. Київ, 2003. $200 \mathrm{c}$.

19. Чуприна Л.А. Інформаційна аналітика в контексті запитів сучасних замовників. Наукові праці Наиіональної бібліотеки України іл. В.І. Вернадського. 2007. Вип. 19. С. 187-193.

\section{Анотація}

Санакуєв М. Г. Місце пошукового алгоритму в глобальному інформаційно-комунікативному просторі та його значення в контент-аналізі. - Стаття.

У статті досліджено особливості інформативно-комунікативного простору в реаліях сьогодення, виокремлено глобальні тенденції, що впливають на нього. Метою дослідження було проаналізувати пошуковий алгоритм у глобальному інформаційно-комунікативному просторі. Предметом дослідження є пошуковий алгоритм як новітня технологія контент-аналізу. Для вивчення пошукового алгоритму та його особливостей використовувалися структурно-функціональний, історико-порівняльний, прогностичний методи дослідження Зокрема, прогностичний підхід дозволив сформулювати рекомендації для вивчення та раціонального застосування сучасних технологій, допоміг розібратися у виявлених тенденціях сучасних соціологічних методів і методик вивчення документів. Історико-порівняльний підхід був використаний у форматі аналізу генези поняття інформаційно-комунікативної взаємодії для відстеження тенденцій змін пошукових технологій в інформаційному просторі. Структурно-функціональний підхід застосовувався в аналізі нових технологічних надбань, які застосовуються в контент-аналізі.

Зміст різних наукових підходів щодо проблем інформаційно-комунікативного простору, які пов'язані з глобалізацією, було узагальнено в результаті дослідження. Місце пошукового алгоритму було визначено в системі інформаційно-комунікативної взаємодії. Причинно-наслідкові зв'язки було виявлено в 
особливостях функціонування пошукового алгоритму в контент-аналізі. На основі аналізу зроблено висновки про вплив глобальних змін на пошукові системи й інформаційно-комунікативний простір. Рекомендації для підвищення ефективності пошуку наукових матеріалів і покроковий механізм дій для користувачів були розроблені, виходячи з практичного досвіду й надбань фахівців у комп'ютерних науках. Подальше застосування практичного досвіду й підвищення ефективності пошуку мають враховувати те, що цільовою тематикою пошуку є саме соціологічні дослідження. Зрештою, автор пропонує застосовувати практичний досвід наукових установ, що діють в Україні. Наукові розробки із цього питання також можуть бути використані для створення прототипів комп'ютерних програм і додатків для пошуку україномовних наукових матеріалів, які будуть вжиті для контент-аналізу.

Ключові слова: пошукові системи, інформаційно-комунікативний простір, Google, алгоритм, стратегічні комунікації, індексування запиту, Internet, контент-аналіз.

\section{Summary}

Sanakuiev M. G. The place of the search algorithm in the global imformation and communicative space and its value in content analysis. - Article.

The article examines the features of the information and communication space in today's realities, and identifies the global trends that affect it. The aim of the study was to analyze the search algorithm in the global information and communication space. The subject of research is the search algorithm, as the latest technology of content analysis. The study of the search algorithm and its features used structural-functional, historical-comparative, predictive research methods.
In particular, the prognostic approach helped to formulate recommendations for the learning and rational application of modern technologies, helped to understand the identified trends of modern sociological methods and techniques of documents studying. Historicalcomparative approach was used in the format of analysis of the genesis of the concept of information-communicative interaction, to follow trends in search technologies in the information space. Structural and functional approach applied in the analysis of new technological assets used in content analysis.

The study summarized the content of various scientific approaches to the problems of information and communication space, which are related to globalization. The place of the search algorithm was determined in the system of information and communication interaction. Causal relationships were found in the features of functioning of the search algorithm in content analysis. Based on the analysis, conclusions are made about the impact of global changes on search engines and information and communication space. Recommendations for improving the search for scientific materials and a step-by-step mechanism of action for users were developed based on the practical experience and expertise of computer science specialists. Further application of practical experience and improving the efficiency of the search should take into account the fact that the target topic of the search is sociological research. In the end, the author proposes to use the practical experience of scientific institutions operating in Ukraine. Scientific developments concerning this issue can also be used to create prototypes of computer programs and applications for searching Ukrainian-language scientific materials that will be used for content analysis.

Key words: search engines, information space, Google, algorithm, strategic communications, query indexing, Internet, content analysis. 